\title{
Studi Kelayakan Neraca Mesin Packing Pada Pengantongan Semen di PT. Semen Tonasa
}

\author{
Haris Tehuayo ${ }^{1}$, Sriwati ${ }^{2}$, Faridah $^{3}$, Sajiah $^{4}$ \\ ${ }^{1,2,3}$ Universitas Islam Makassar, Makassar, Sulawesi Selatan,Indonesia \\ Email: ${ }^{1}$ harisristo02@gmail.com, ${ }^{2}$ sriwati.dty@uim-makassar.ac.id \\ ${ }^{3}$ faridah. dty@uim-makassar.ac.id, ${ }^{4}$ informatikasajiah@gmail.com
}

\begin{abstract}
From year to year technological improvement is guite significant, it is also marked by the emergence of various kinds of technology, especially the balance sheet. In the balance sheet needs calibration. Calibration is usually done by comparing standards that are linked to national standards as well as international standards and certified reference materials. Metrological board and the government perform the calibration process within a predetermined time frame in order to minimize the occurrence of scales deviations. To see the results of the three balance sheets taking samples, comparing the three sample types to see the guality and guality of the balance sheet so that it will clear the balance sheet efficiently and inefficiently.
\end{abstract}

Keywords-Haver\&boecker, IQ-Plus, Redlion, efficiency, accurancy

Intisari-Dari tahun ke tahun peningkatan teknologi cukup signifikan, hal ini di tandai dengan munculnya berbagai macam teknologi khususnya neraca. Dalam neraca tersebut dibutuhkan pengkalibrasian, kalibrasi biasa dilakukan dengan membandingkan suatu standar yang terhubung dengan standar nasional maupun internasional dan bahan-bahan acuan tersertifikasi. Badan metrologi dari pemerintah melakukan proses kalibrasi dalam jangka waktu yg telah di tentukan guna meminimalisir terjadinya penyimpangan timbangan. Untuk melihat hasil dari ketiga jenis neraca, maka perlu dilakukan pengambilan sampel, membandingkan ketiga jenis sampel tersebut guna untuk melihat mutu dan kualitas neraca, sehingga dengan begitu akan tampak jelas neraca mana yang sangat efisien dan yang tidak. Studi Kelayakan Neraca Mesin Packing Pada Pengantongan Semen Di PT. Semen Tonasa ini merupakan suatu pertimbangan dalam pemilihan timbangan yang mengacu pada kemajuan teknologi yang lebih efisien baik dalam proses kalibrasi, pengoperasian, perawatan maupun keakurasiannya. Tingkat keakurasian suatu timbangan dapat dilihat dari pengecekan timbangan secara berkala, sehingga disimpulkan bahwa neraca IQ-Plus dan Redlion lebih baik daripada neraca Haver\&boecker, tetapi jika ingin alat dan bahan yg mudah didapatkan dan tentunya lebih mudah pengerjaannya maka Redlion merupakan pilihan yang tepat.

Kata Kunci-Haver\&boecker, IQ-Plus, Redlion, efisiensi, akurasi

\section{PENDAhuluan}

Seiring berkembangnya ilmu pengetahuan dan teknologi yang menjadi bagian terpenting dalam sejarah perkembangan dunia. Tekonologi dalam timbangan/ neraca berkembang cukup pesat, hal ini dibuktikan dengan munculnya berbagai merk dan jenis alat timbang. Alat timbang/neraca ini muncul dengan variasi bentuk, ukuran dan tingkat keakurasian yang berbeda-beda, hal ini yang menjadi tolak ukur pemilihan alat timbang, dan merupakan panduan dalam memilih jenis yang terbaik dalam proses pengukuran.Dengan adanya timbangan ini, maka perlu diketahui cara kerja peralatan maupun teknik kalibrasinya.

Secara umum kalibrasi mempunyai pengertian sebagai rangkaian kegiatan membandingkan hasil pengukuran suatu alat dengan alat standar yang sesuai untuk menentukan besarnya koreksi pengukuran alat serta ketidakpastiannya. Dalam pengertian ini alat standar yang digunakan juga harus terkalibrasi dibuktikan dengan sertifikat kalibrasi. Dengan demikian maka besarnya koreksi pengukuran alat dapat ditelusurkan ke standar nasional atau standar internasional dengan suatu mata rantai kegiatan kalibrasi yang tidak terputus.

Alat ukur yang telah dikalibrasi tidak akan secara terus menerus berlaku masa kalibrasinya, karena peralatan tersebut selama masa penggunaanya pasti mengalami perubahan spesifikasi akibat pengaruh frekuensi pemakaian, lingkungan penyim-panan, cara pemakaian, dan sebagainya. Untuk itulah selama berlakunya masa kalibrasi alat bersangkutan perlu dipelihara ketelusurannya dengan cara perawatan dan cek antara secara periodik.

Hasil pengukuran yang diberikan oleh beberapa alat sejenis tidak selalu menunjukkan hasil yang sama, meskipun alat tersebut mempunyai tipe yang sama. Perbedaan ini diperbesar lagi dengan adanya pengaruh lingkungan, operator, serta metode pengukuran. Padahal dalam menghasilkan hasil pengukuran tersebut sangat diharapkan bahwa setiap alat ukur yang digunakan dimanapun memberikan hasil ukur yang sama dalam kaitannya dengan keperluan keamanan, kesehatan, transaksi, dan keselamatan.

Agar setiap alat dapat memberikan hasil ukur dengan keabsahan yang sama, alat ukur tersebut perlu mempunyai ketelusuran kepada standar nasional atau standar internasional. Cara untuk memberikan jaminan bahwa alat yang digunakan mempunyai ketelusuran kepada standar nasional adalah dengan melakukan kalibrasi terhadap alat tersebut. Lebih dari itu untuk memelihara ketelusuran tersebut perlu dilakukan perawatan alat dalam selang kalibrasi tertentu.

Dalam penerapan standar ISO/IEC 17025: 2005, kiranya upaya-upaya untuk menyamakan persepsi bagi semua pihak terkait perlu dilaksanakan. Ketelusuran 
pengukuran tidak hanya sekedar menjadi persyaratan administratif, melainkan telah menjadi kebutuhan teknis yang mendasar terutama dengan diwajibkannya mencantumkan estimasi ketidakpastian dalam hasil uji [1].

\section{LANDASAN TEORI}

\section{A. Timbangan}

Timbangan adalah alat yang dipakai melakukan pengukuran massa suatu benda. Timbangan/neraca dikategorikan kedalam sistem mekanik dan juga elektronik /Digital. Dalam pengoperasian neraca ada beberapa faktor yang mempengaruhi neraca tersebut, yaitu kalibrasi, akurasi, dan presisi.

Dalam pengoperasian neraca tersebut perlu di lakukan kalibrasi dimana kalibrasi menurut ISO/IEC Guide 17025:2005 dan Vocabulary of International Metrology (VIM) adalah serangkaian kegiatan yang membentuk hubungan antara nilai yang ditunjukkan oleh instrumen ukur atau sistem pengukuran, atau nilai yang diwakili oleh bahan ukur, dengan nilai-nilai yang sudah diketahui yang berkaitan dari besaran yang diukur dalam kondisi tertentu [2].
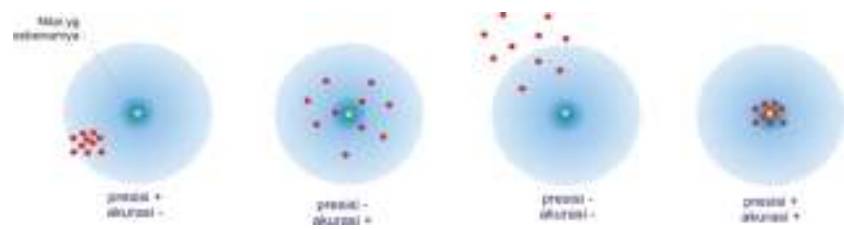

Gambar 1. Presisi dan Akurasi

\section{B. PLC (Programmable Logic Controller)}

Menurut National Electrical Manufacturing Assosiation (NEMA), PLC didefinisikan sebagasi suatu perangkat elektronik digital dengan memori yang dapat diprogram untuk menyimpan instruksi-instruksi yang menjalankan fungsi-fungsi spesifik seperti: logika, sekuen, timing, counting, dan aritmatika untuk mengontrol suatu mesin industri atau proses industri sesuai dengan yang diinginkan. PLC mampu mengerjakan suatu proses terus menerus sesuai variabel masukan dan memberikan keputusan sesuai keinginan pemrograman sehingga nilai keluaran tetap terkontrol [3].

\section{Load cell}

Load cell adalah alat yang mengeluarkan signal listrik proporsional dengan gaya / beban yang diterimanya. Load cell banyak digunakan pada timbangan elektronik. Jembatan Wheatstone yang tersusun seperti gambar 3 merupakan diagram sederhana load cell. Resistor yang bertanda T1 dan T2 merupakan Strain Gauge yang menerima gaya tarik(Tension) saat load cell menerima beban. Sedangkan resistor yang bertanda C1 dan C2 adalah Strain Gauge yang menerima gaya tekan (Compression) ketika load cell dibebani.

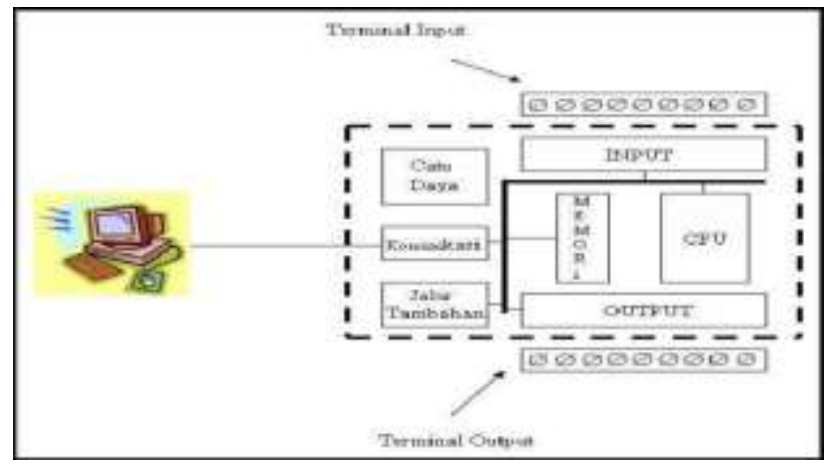

Gambar 2. PLC

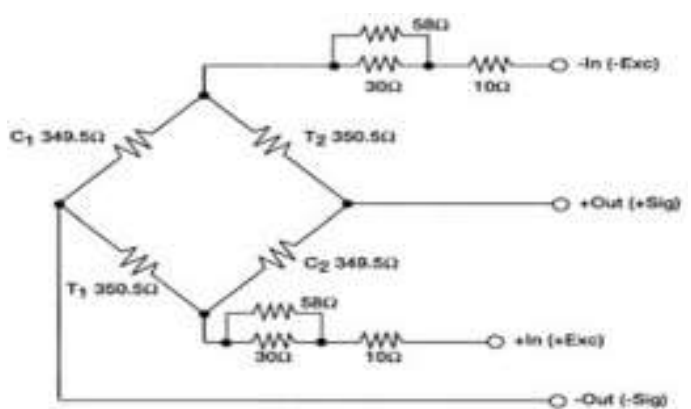

Gambar 3. Load cell[4]

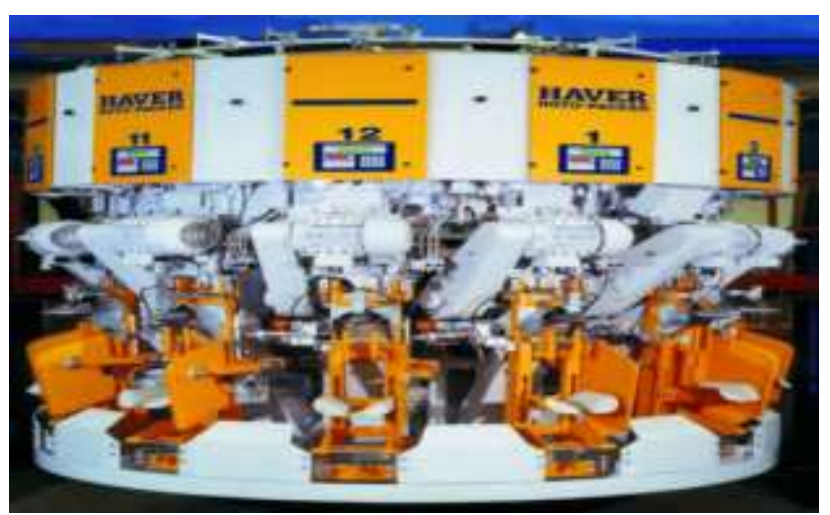

Gambar 4. Haver Roto-Packer 12 spout

\section{Haver \& Boecker}

Pada tahun 1960 Haver Roto Packer yang merupakan perusahaan yang terdaftar di Jerman memproduksi mesin pengisian kantong yang terdiri dari 3-16 spout/corong pengisian. Pada tahun 1987 Dr. Reinhold Festge and Dipl.-Ing. Walter Haver masuk ke perusahaan ini dan menjaganya agar tetap kokoh dan berkomitmen untuk mempertahankan dan memperluas kepemimpinan teknologi. Dibawah arahan mereka beberapa perusahaan seperti IBAU HAMBURG (Hamburg, Germany), BEHN BATES, Münster, Germany, FEIGE Filling Technology, Bad Oldesloe, Germany, W.S. TYLER, USA and Canada, as well as the founding of Haver \& Boecker Iberica, Barcelona/Spain, HAVER TRADING, Poland, HAVER SUISSE, HAVER IBAU SHENZHEN, China, and HAVER FILLING TECHNOLOGY (Beijing), China, as well as HAVER RUSSIA and HAVER MEXICANA telah diambil alih. Hal ini telah membuat perusahaan ini sangat strategis untuk mencapai pelanggannya di seluruh dunia[5]. 
Gambar mesin Haver Roto Packer oleh Haver dan Boecker dapat dilihat pada Gambar 4.

\section{E. Redlion}

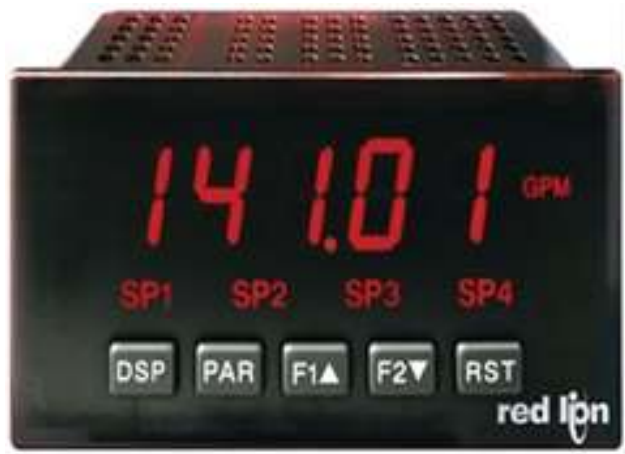

Gambar 5. Bentuk Fisik Redlion

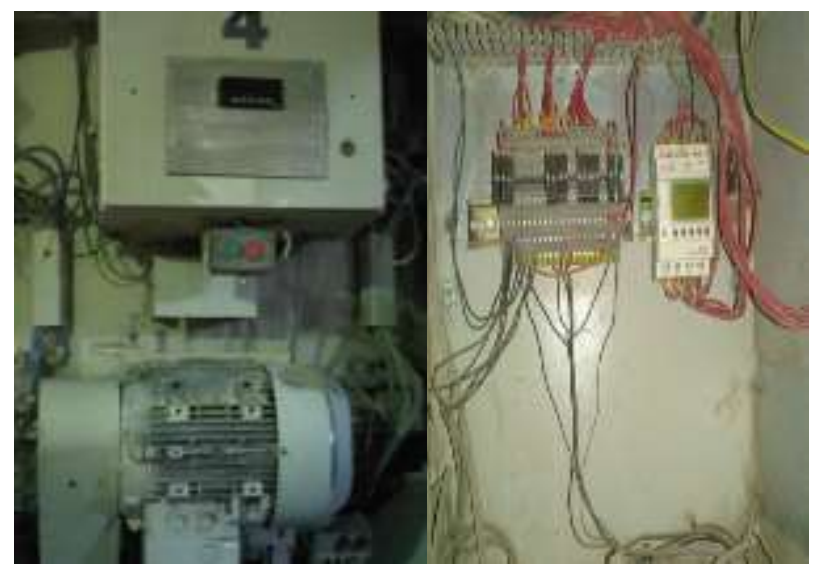

Gambar 6. Kontrol Panel Redlion [6]

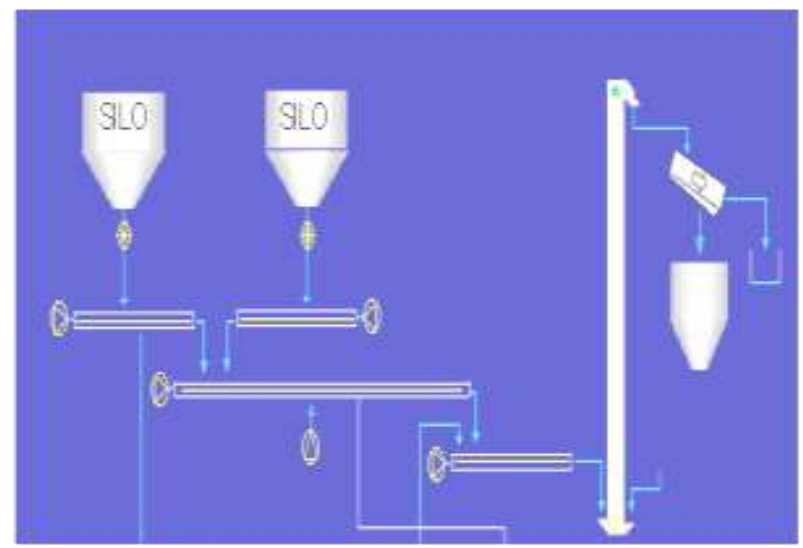

Gambar 7. Sistem Pengisian Semen Secara Otomatis

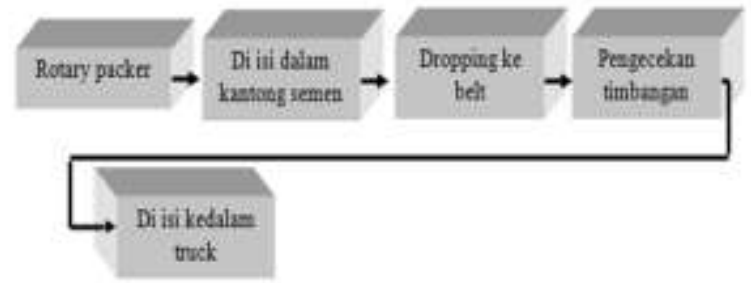

Gambar 8. Sistem pengisian secara manual

Redlion merupakan suatu bentuk display yang dapat digunakan sebagai indikator, dalam hal ini digunakan sebagai indikator berat $(\mathrm{kg})$ yang di sinkronkan dengan loadcell sebagai alat timbangnya. Intensitas layar dapat disesuaikan dari aplikasi sehingga dalam ruangan gelap sekalipun hingga sinar matahari terang layar dapat dibaca, sehingga sangat ideal untuk digunakan. Semua konduktor harus sesuai dengan tegangan meter dan semua kabel harus sesuai dengan standar yang sesuai baik instalasi, kode dan peraturan lokal. Disarankan bahwa daya yang disediakan ke meter (DC atau AC) dilindungi dengan sekering atau pemutus sirkuit yang berguna sebagai pengaman. Adapun gambar tampilan layar red lion dapat dilihat pada Gambar 5.

\section{METODE PENELITIAN}

Dalam penelitian ini digunakan 2 metode yakni: 1) Mengamati dan menganalisa (Hal ini digunakan untuk mengetahui kerja peralatan dan mengetahui penyebab yang timbul terhadap peralatan dengan kondisi lapangan yang berdebu). 2) Menentukan dan menuliskan data kalibrasi (Hal ini digunakan untuk mengetahui peralatan mana yang sering dikalibrasi dan mengetahui perbandingan antar setiap peralatan).

\section{Sistem Pengisian Semen}

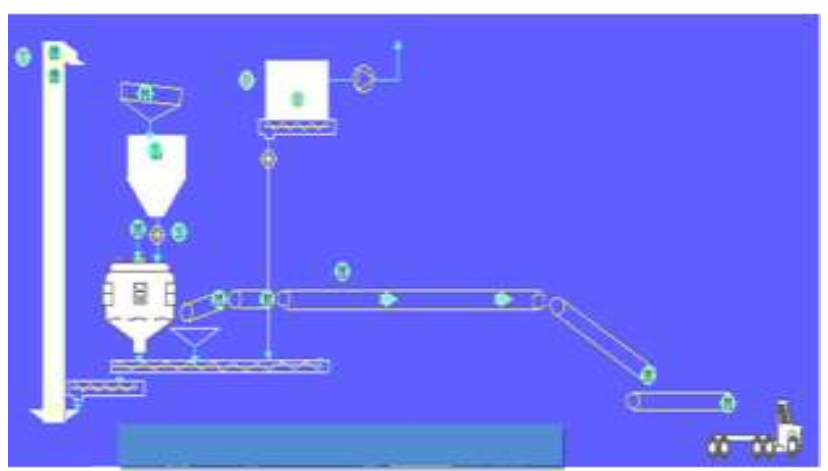

Gambar 9. Pengisian dari silo semen ke packer

Keterangan Gambar 9. Material yang kasar berupa batu, coating maupun sampah-sampah yang terikut dalam vibrating screen tersebut dibuang melalui pipa pembuangan sedangkan material halus (semen) di salurkan kedalam bin (penampugan sementara) kemudian diteruskan kedalam rotary packer sehingga dapat di isi dalam kantong semen.

Material yang masuk dalam rotary packer tersebut kemudian diisi dalam kantong semen baik itu semen $50 \mathrm{~kg}$ maupun semen $40 \mathrm{~kg}$, kemudian dengan otomatis sesuai program masing-masing neraca, kantong semen tersebut di dropping ke belt yang menuju ke truck, sebelum menuju ke truck dilakukan pengecekan timbangan dimana semen yang jalan diatas belt ditarik dan diangkat menuju timbangan portable untuk diambil sample dari masingmasing neraca yang telah dijelaskan sebelumnya.

\section{Flow Chart sistem pengambilan data}

Dari penjelasan singkat diatas maka dapat dibuat flow chart tentang proses pengambilan sample dan peralatan mana yang lebih efisien untuk digunakan sebagai alat pengisian 


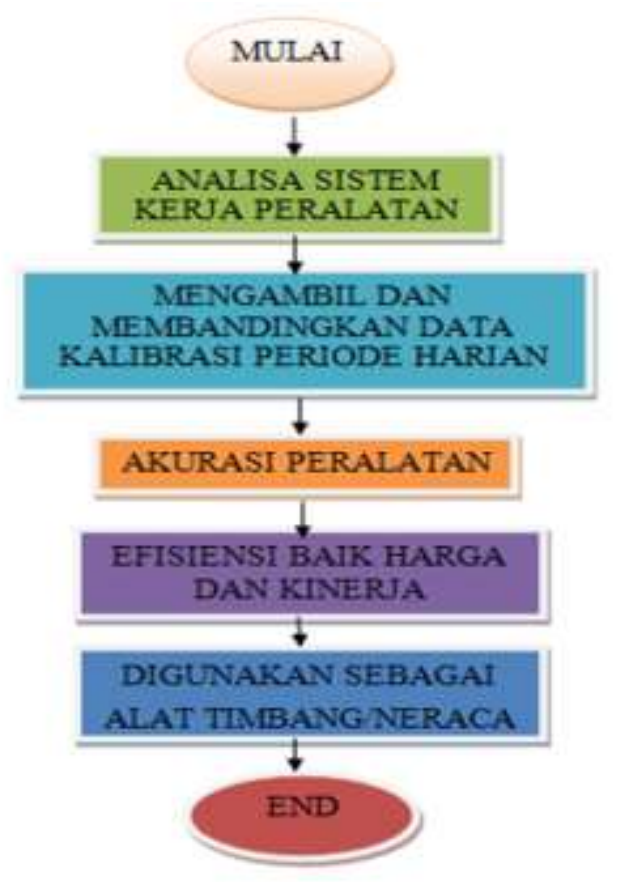

Gambar 10. Flowchart sistematis penelitian neraca

\section{HASIL DAN PEMBAHASAN}

Dalam hasil penelitian ini, yang akan dilakukan adalah membandingkan tiga jenis neraca dimana pengambilan sample dilakukan tiga kali dalam kurun waktu satu minggu, yakni senin, rabu dan jum'at, hal ini untuk memudahkan melihat perbedaan ketiga neraca tersebut. Berikut ketiga jenis neraca tersebut.

\section{A. Haver \& Boecker}

Perubahan atau variasi timbangan dapat terjadi karena dipengaruhi beberapa faktor antara lain:

1. Tingkat kehalusan semen dan jenis kantong yang digunakan,

2. Keadaan mekanis pengisian semen, dan

3. Nilai / parameter suatu peralatan yang memiliki range terlalu tinggi.

Dalam proses kerjanya peralatan Haver \& Boecker terdiri dari:

1. Peralatan kontrol / Elektrikal yakni:
a. MCB
b. Kontaktor,
c. Terminal,
d. Kabel
e. Bagclamp,
f. Sensor proximity
g. Card Elektronika yang terdiri dari 5 card,
h. Motor 3 phasa,
i. Loadcell, dan
j. Display sebagai tampilan.

2. Peralatan mekanis yang saling terkait, yakni:
a. Piston,
b. Spout / corong,
c. Impeller,
d. V-belt, dan beberapa peralatan yang saling mendukung antara satu dengan yang lain.

Adapun estimasi biaya yang diperlukan untuk pengadaan 1 buah spout Haver \& Boecker dari segi elektrikal/kontrolnya sebagai berikut:

Tabel I.

Estimasi biaya untuk satu panel Haver\&Boecker

\begin{tabular}{|c|l|r|}
\hline No. & \multicolumn{1}{|c|}{ Jenis Peralatan } & Harga (Rp) \\
\hline 1. & Rel & 15.000 \\
2. & Terminal & 350.000 \\
3. & Kabel & 20.000 \\
4. & MCB 3 phasa & 135.000 \\
5. & MCB 1 phasa & 60.000 \\
6. & Kontaktor & 185.000 \\
7. & Bagclamp & 2.000 .000 \\
8. & Sensor proximity x2 & 1.000 .000 \\
9. & Selenoid x4 @ 180.000 & 720.000 \\
10. & Box solenoid/manifold & 2.000 .000 \\
11. & Loadcell & 1.500 .000 \\
12. & Display sebagai tampilan sudah & 85.000 .000 \\
& termasuk card elektronika x 5 \\
\multicolumn{2}{|c|}{ Total } & \\
\hline \multicolumn{2}{|c|}{} \\
\hline
\end{tabular}

Adapun cara kalibrasi peralatan neraca Haver \& Boecker adalah sebagai berikut:

1. Sebelum melakukan calibrasi kondisi dudukan kantong semen harus bersih,dan harus bebas

2. Perhatikan card converter ( ST 39 ) dan Power suplay dalam keadaan $\mathrm{ON}$, setelah itu ikuti langkah-langkah berikut ini:

a. Geser ke kanan swith SW3 pada card ST 39, lalu perhatikan tampilan display

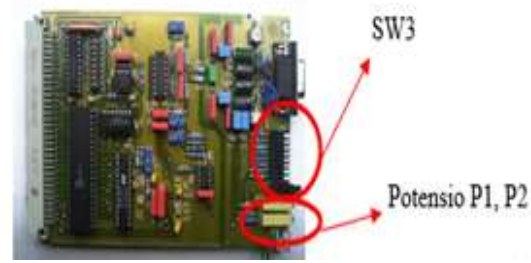

Gambar 11. card converter

b. Jika terlalu jauh dari nilai $2,30 \mathrm{Kg}$ (zero/tara) geser Swith SW2 sampai muncul pada display nilai yang mendekati $2,30 \mathrm{Kg}$.

c. Putar potensio P2 sampai muncul pada display 2,30 $\mathrm{Kg}$ (zero/tara)

d. Naikkan beban pemberat $50 \mathrm{Kg}$, lalu amati tampilan display $52,30 \mathrm{Kg}$ (span) jika tidak putar potensio P1 sampai muncul persis sama dengan $52,30 \mathrm{Kg}$

e. Turunkan beban pemberat, amati zero $2,30 \mathrm{Kg}$ jika tidak sama ulangi dari poin b sampai poin d,

f. Setelah itu geser SW3 ke kiri dan coba lagi naikkan beban $50 \mathrm{Kg}$ amati pada dispay jika tidak sama dengan 50,00 $\mathrm{kg}$ ulangi proses calibrasi, dari poin a sampai poin $\mathrm{f}$ dan jika sudah sama dengan $50,00 \mathrm{~kg}$ maka proses kalibrasi sudah selesai.

3. Jika hanya ingin menaikkan atau menurunkan timbangan maka cukup putar Potensio P1 atau P2 untuk mencapai timbangan yang diinginkan. 
B. IQ-Plus

IQ-Plus ini merupakan neraca modifikasi oleh Delta Surabaya yang diperuntukkan untuk scala besar yang mampu mencapai 2000 ton, IQ-Plus ini sedikit lebih canggih dibandingkan neraca Haver \& Boecker, karena sudah menggunakan PLC sebagai pengganti card elektronik.

PLC yang digunakan dalam neraca IQ-Plus ini menggunakan PLC Siemens Logo.

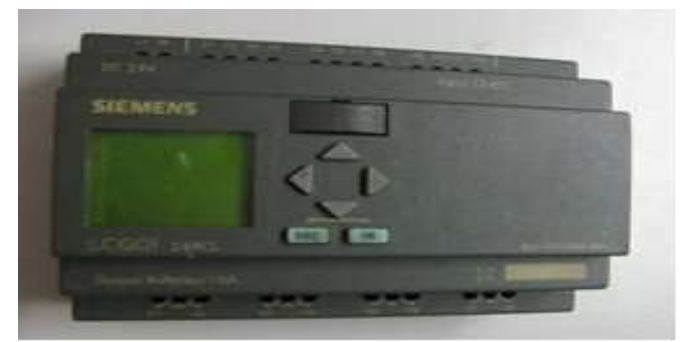

Gambar 12. PLC Logo

Untuk Membuat satu peralatan kontrol neraca IQ-Plus di berlukan beberapa jenis alat, berikut harga dan jenis peralatannya

Tabel II.

Estimasi Biaya IQ-PLUS

\begin{tabular}{|c|l|r|}
\hline No. & \multicolumn{1}{|c|}{ Jenis Peralatan } & Harga (Rp) \\
\hline 1. & PLC Siemens & 3.500 .000 \\
2. & Power Suplay 24 Vdc & 2.000 .000 \\
3. & Indikator Weighing (IQ- & 17.000 .000 \\
4. & Plus 710) & 60.000 \\
5. & Circuit Breaker 220 VAC & 500 \\
6. & Fuse 3.5 A & 180.000 \\
7. & Relay 24 Vdc, 2 NO+2NC & 250.000 \\
8. & Limit Switch & 1.000 .000 \\
9. & Sensor Proximity x 2 & 80.000 \\
10. & Indikator lamp & 56.000 \\
11. & Saklar Push Button & 1.500 .000 \\
12. & Load cell & 135.000 \\
13. & MCB 3 phasa @ 180.000 & 185.000 \\
14. & Kontaktor & 2.000 .000 \\
15. & Bagclamp & 720.000 \\
16. & Selenoid x 4 & 2.000 .000 \\
17. & Box solenoid (manifold) & 15.000 \\
18. & Rel & 350.000 \\
19. & Terminal & 20.000 \\
& Kabel & \\
\hline \multicolumn{2}{|c}{ Total } & Rp. 31.051.500 \\
\hline
\end{tabular}

PLC ini merupakan pengganti relay dan merupakan suatu program yang menjalankan fungsi-fungsi pengisian, dalam pengoperasiannya PLC ini dapat menggunakan 2 mode, baik itu mode ledder diagram maupun mode gerbang Logika baik itu AND, OR, NAND, XOR dan NOT. Pada neraca tersebut menggunakan mode gerbang logika seperti pada gambar berikut

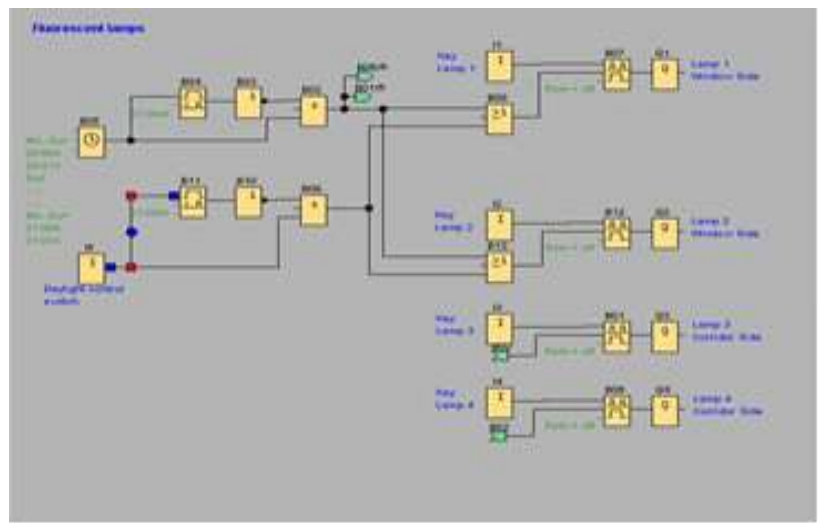

Gambar 13. PLC LOGO Mode Gerbang Logika

C. Redlion

Redlion juga merupakan neraca modifikasi dimana dalam pengoprasiannya, neraca ini menggunakan PLC Zelio, PLC ini merupakan penganti relay yang berfungsi untuk menggantikan proses pengisian semen. Bentuk PLC Zelio tersebut dapat dilihat pada Gambar 14.

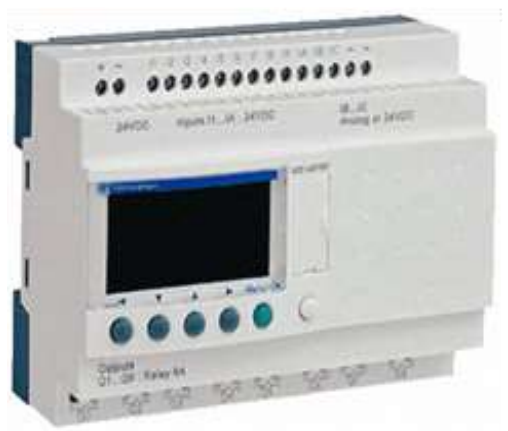

Gambar 14. PLC Zelio

PLC Zelio ini dapat menggunakan program dalam dual tampilan baik itu ledder maupun bentuk gerbang logika.

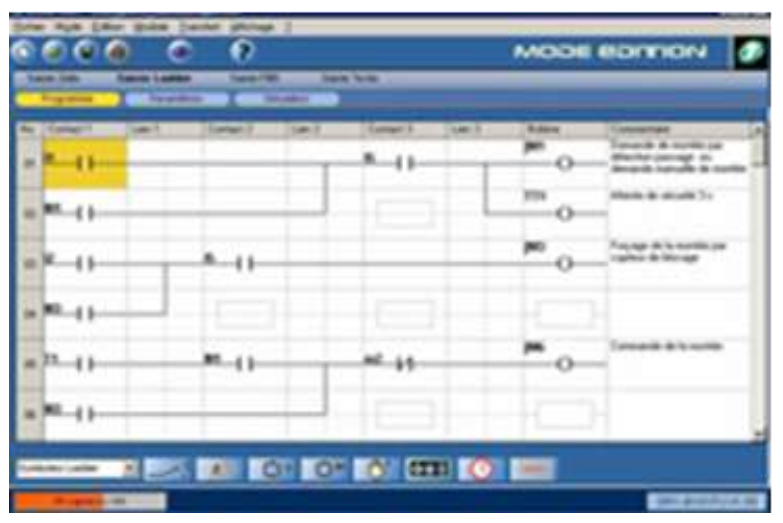

Gambar 15. PLC Zelio dalam bentuk Ledder 


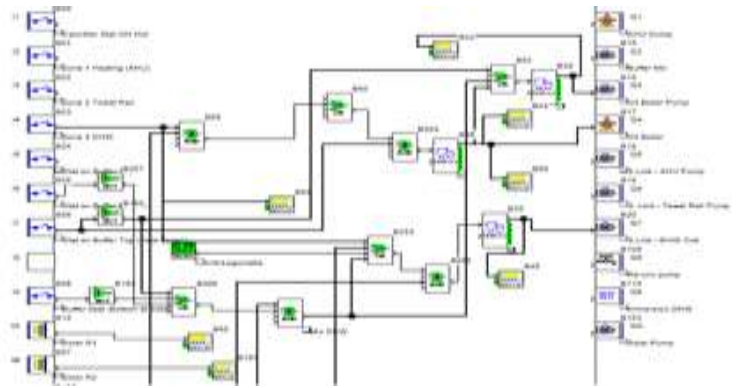

Gambar 16. PLC Zelio dalam bentuk gerbang logika

PLC inilah yang kemudian akan menjalankan perintah pengisian semen dan kemudian di sinkronisasikan oleh redlion dan loadcell, redlion tersebut akan memberikan penunjukan nilai suatu neraca melalui loadcell (alat timbang) Untuk Membuat satu peralatan kontrol yang menggunakan Redlion ini dibutuhkan beberapa peralatan dan estimasi biaya yang dibutuhkan sebagai berikut.

Tabel III.

Tabel Estimasi Biaya Redlion

\begin{tabular}{|l|l|r|}
\hline No. & \multicolumn{1}{|c|}{ Jenis Peralatan } & Harga (Rp) \\
\hline 1. & PLC Zelio & 1.500 .000 \\
2. & Redlion & 2.000 .000 \\
3. & Power Suplay 24 Vdc & 500.000 \\
4. & schneider & 60.000 \\
5. & Circuit Breaker 220 VAC & 180.000 \\
6. & Relay 24 Vdc, 2 NO+2NC & 250.000 \\
7. & Limit Switch & 1.000 .000 \\
8. & Sensor Proximity x 2 & 1.500 .000 \\
9. & Load cell & 135.000 \\
10. & MCB 3 phasa & 185.000 \\
11. & Kontaktor & 2.000 .000 \\
12. & Bagclamp @ 180.000= & 540.000 \\
13. & Selenoid x 3 & 2.000 .000 \\
14. & Box solenoid (manifold) & 15.000 \\
15. & Rel & 350.000 \\
16. & Terminal & 20.000 \\
\multicolumn{2}{|c|}{ Total } & Kabel \\
\hline
\end{tabular}

Untuk menjalankan perintah pengisian semen, PLC Zelio dirangkai dengan beberapa peralatan lainnya, untuk lebih jelasnya dapat dilihat pada gambar berikut.

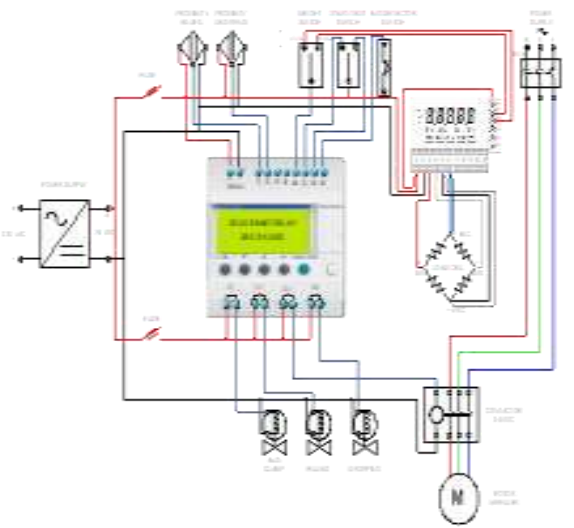

Gambar 17. Rangkaian pengawatan kontrol Redlion

\section{Kalibrasi Neraca}

Tabel IV

Perbandingan data kalibrasi ketiga jenis neraca

Pada tabel diatas dapat dilihat dengan jelas, bahwa neraca yang menggunakan Redlion merupakan neraca

\begin{tabular}{|c|c|c|c|c|c|c|c|}
\hline \multirow{2}{*}{ No. } & \multirow{2}{*}{$\begin{array}{c}\text { Jenis } \\
\text { Neraca }\end{array}$} & \multicolumn{6}{|c|}{ Kalibrasi $( \pm 0.5)$} \\
\cline { 3 - 8 } & & \multicolumn{2}{|c|}{ I } & \multicolumn{2}{|c|}{ II } & \multicolumn{2}{|c|}{ III } \\
\hline 1 & $\begin{array}{c}\text { Haver \& } \\
\text { Boecker }\end{array}$ & 41.0 & 40.7 & 41.0 & 41.1 & 40.8 & 40.7 \\
\hline 2 & IQ-Plus & 40.1 & 40.7 & 40.3 & 41.0 & 41.1 & 40.3 \\
\hline 3 & Redlion & 40.2 & 40.2 & 40.0 & 40.2 & 40.2 & 40.2 \\
\hline
\end{tabular}

yang cenderung lebih stabil, penunjukan pada layar Redlion sama dengan berat per kg pada kantong semen tersebut. Untuk pembuktian nilai penunjukan dan berat kantong per kgnya sama adalah dengan menimbang secara manual kantong semen yang telah terisi tersebut pada neraca konvensional / timbang manual.

Dari penjelasan sebelumnya juga telah dijelaskan bahwa Redlion merupakan sebuah alat yang dalam perakitannya lebih simpel dan ekonomis serta lebih mudah untuk di maintenance.

\section{Perbandingan Harga}

Jika dilihat dari segi harga maka dapat dibandingkan secara jelas neraca mana yang lebih menguntungkan, berikut perbandingannya.

Tabel V.

Perbandingan harga ketiga jenis Neraca

\begin{tabular}{|c|c|c|}
\hline No. & Jenis Neraca & Total Harga (Rp) \\
\hline 1 & Haver \& Boecker & 92.985 .000 \\
\hline 2 & IQ-Plus & 31.051 .500 \\
\hline 3 & Redlion & 12.235 .000 \\
\hline
\end{tabular}

\section{Perbandingan Nilai Kalibrasi}

Dari data yang telah diperoleh (lihat lampiran) maka setiap neraca pasti memiliki hasil timbangan yang tidak sama persis, hal ini diakibatkan oleh beberapa faktor diantaranya telah dijelaskan pada penjelasan kalibrasi setiap peralatan dan faktor yang lebih spesifik dapat dilihat dibawah ini.

- Dalam setiap sampel yang diambil akan terjadi perbedaan berat antara sample satu dan dua hal ini sangat dipengaruhi oleh keadaan system mekanis, baik itu keadaan meja kantong, posisi spout maupun keadaan stik loadcell yang memiliki kemiringan yang tidak standar, beberapa diantaranya dapat dilihat pada gambar berikut:

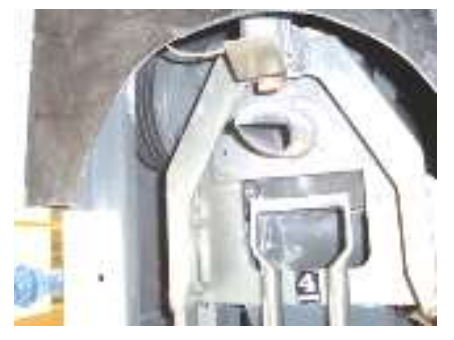

D. Perbandingan ketiga jenis Neraca 


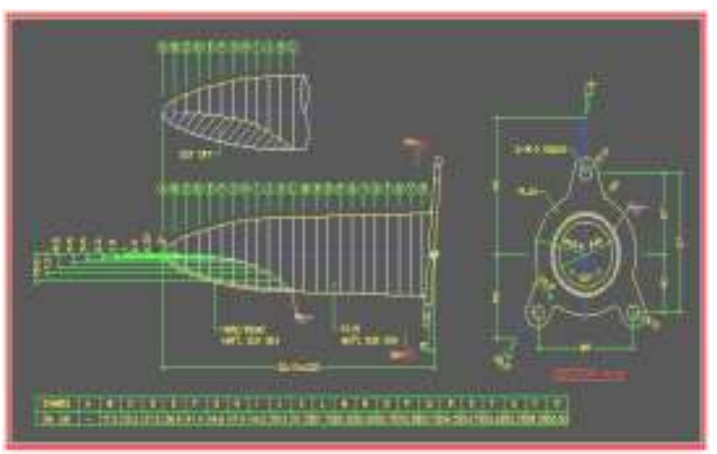

Gambar 18. spout/corong rotary packer

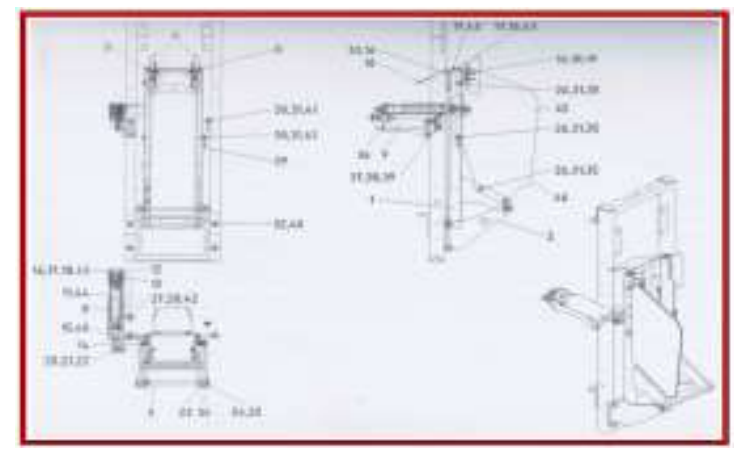

Gambar 19. posisi meja kantong

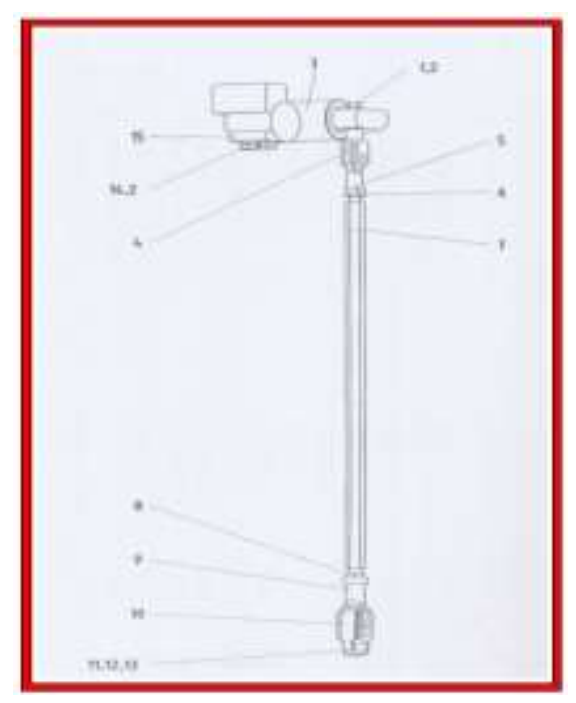

Gambar 20. stik loadcell

Hal inilah yang juga mempengaruhi nilai timbangan

- Penyimpangan nilai yang timbul pada neraca juga dipengaruhi oleh range peralatan yang besar, hal ini dapat dilihat dari tampilan display dan berat kantong yang tidak sesuai, selain itu neraca yang menggunakan IQ-Plus dan redlion menggunakan digital output sebagai kluarannya sehingga berat yang terisi lebih akurat,

- Parameter yang telah di settingkan bergeser oleh karena adanya getaran, perubahan system mekanis, maupun karena adanya faktor lainnya yang tidak diketahui.
Tingkat efisiensi juga dilihat dari sistem kerja peralatan, cara kalibrasi yang mudah, pemasangan yang simple dan tentu saja ketersediaan alat dan bahan serta harga yang ditawarkan,

Dari beberapa alasan yang telah dimuat dalam isi laporan kalibrasi ini maka beberapa faktor utama pemilihan neraca redlion adalah sebagai berikut:

- Neraca yang menggunakan Redlion lebih murah biayanya untuk pengadaan satu unit control spout dibandingkan haver \& Boecker ataupun IQ-Plus,

- Berat kantong yang terisi sama dengan yang tertera pada layar,

- Hasil timbangan yang lebih stabil jika dilihat dari hasil pengkalibrasian hariannya.

Dari data yang telah diperoleh, maka kontrol menggunakan Redlion telah menjadi suatu kemajuan dan menciptakan suatu peralatan yang lebih baik dari apa yang telah ada sebelumnya, tentunya dengan perbaikan kearah yang lebih baik lagi untuk kedepannya.

\section{KESIMPULAN}

Dari hasil analisa dan pengumpulan data untuk menjawab tujuan dari penelitian ini, maka dapat ditarik kesimpulan sebagai berikut.

1. Neraca Haver \& Boecker merupakan neraca yang masih menggunakan card elektronika yg rentan mengalami kerusakan sehingga neraca tersebut telah dimodifikasi menggunakan IQ-Plus maupun Redlion. beberapa dari neraca tersebut memiliki tingkat kalibrasi yang bervariasi. Beberapa penyebab perlunya neraca tersebut dikalibrasi, antara lain.

a. Nilai timbangan bergeser dari target,

b. Terjadi penyimpangan-penyimpangan dari range yang telah ditentukan.

2. Jika dilihat dari sisitem kerja masing-masing neraca, maka dari pembahasan sebelumnya dapat dilihat neraca mana yang memiliki keakuratan lebih baik, untuk kantong $40 \mathrm{~kg}$ misalnya Haver \& Boecker bisa mencapai $41.2 \mathrm{~kg}$, IQ-plus $40.7 \mathrm{~kg}$ sedangkan untuk Redlion $40.2 \mathrm{~kg}$. Dari Hasil penelitian yang kami lakukan, maka neraca yang menggunakan Redlion lebih akurat dibandingkan neraca jenis lainnya.

3. Redlion merupakan neraca yang lebih efisien, hal ini dibuktikan dari berbagai aspek, antara lain yakni.

a. Untuk pengadaan sebuah kontrol Haver \& Boecker diperlukan dana sekitar Rp. 92.985.000 yang telah dibahas rinciannya pada halaman-halaman sebelumnya,

b. Sedangkan untuk IQ-Plus dibutuhkan dana sebesar Rp. 31.051.500 dan Redlion hanya memerlukan Rp. 12.235.000,

c. Range yang ditimbulkan oleh neraca yang menggunakan Redlion lebih kecil, sehingga berat kantong sesuai target yang diinginkan, juga ketersediaan peralatan cukup memadai, karena alatnya mudah didapatkan.

\section{UCAPAN TERIMA KASIH}

Penelitian ini didanai oleh Kemenristek Dikti dalam hibah Dosen Pemula 2019 


\section{REFERENSI}

[1] Camino-Sánchez, F., et al., UNE-EN ISO/IEC 17025: 2005 accredited method for the determination of 121 pesticide residues in fruits and vegetables by gas chromatography-tandem mass spectrometry. 2011. 24(3): p. 427-440.

[2] Omar, A.S., Development of Colour-mark Sensorbased Calibration System for Timing Devices with Seven-segment Liquid-crystal-display. 2015, Universiti Teknologi Malaysia.

[3] Suyanto, S. and D.J.G. Yulistyawan, Otomatisasi Sistem Pengendali Berbasis PLC Pada Mesin Vacuum Metalizer Untuk Proses Coating (Studi Kasus Di Pt. Astra Otoparts, Tbk-Divisi Adiwira Plastik, Bogor). 2009. 9(2).

[4] Syech, R., R. Abdi, and W.J.J.A. Tambunan, Penentuan Konduktivitas Listrik Air Sungai Batang Lubuh dengan Menggunakan Metode Jembatan Wheatstone. 2016. 8(2): p. 92-101.

[5] KING, D., THE HISTORY OF THE WOVEN WIRE INDUSTRY-HAVER-AND-BOECKER ON THE OCCASION OF THEIR IOOTH ANNIVERSARYGERMAN-PIERENKEMPER, T, TILLY, R. 1988, FRANK CASS CO LTD 11 GAINSBOROUGH ROAD, LONDON, ENGLAND E11 1RS.

[6] Kent, D.V. and F.W. Kent, Neighbours and Neighbourhood in Renaissance Florence: The District of the Red Lion in the Fifteenth Century. Vol. 6. 1982: JJ Augustin. 